\title{
Stock Market Reaction To Chief Marketing Officer Appointment Announcements
}

Nikos Vafeas, University Of Cyprus, Cyprus

Adamos Vlittis, University Of Nicosia, Cyprus

\begin{abstract}
This paper investigates the stock price performance of 166 firms appointing a new Chief Marketing Officer (CMO) between 1999 and 2005. Following event study methodology, the results reveal that abnormal stock returns around the appointment day are greater for firms appointing a CMO with prior marketing executive experience, in firms where the new CMO explains the intended future marketing strategy on the appointment announcement day, whereas it is lower in firms operating in higher growth, high technology industries with higher product differentiation. Announcement-induced returns are also greater for firms that experienced poor stock price performance in the year leading to the appointment. Taken together, the results suggest that the market's assessment of a change in marketing leadership should not be viewed as being uniformly beneficial, but should be assessed against the profile of the appointee and the appointing firm.
\end{abstract}

Keywords: M executive appointments; executive experience; marketing strategy; event study

\section{INTRODUCTION}

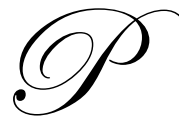

rior literature which studied the selection of new corporate executives focused primarily on CEOs. Nevertheless, in addition to the CEO, a broad team of other top managers contributes towards making important strategic decisions for the firm, which are also likely to have an impact on its performance (e.g., Hambrick, Cho, and Chen 1996). Academic research has gradually expanded to capture this possibility, studying how the market values turnover of the top management team in general (e.g., Lee and James 2007) and the importance of specific executive positions just below the CEO, such as the COO, in particular (e.g., Hambrick and Canella 2004; Zhang 2006). The present research note adds to this stream of research by studying the market's assessment to the appointment of new Chief Marketing Officers (CMOs).

Our approach is to assess and attempt to empirically explain the market reaction to CMO appointments using event-study methodology. This study is interesting for several reasons. First, it complements and contrasts existing research on executive turnover in general, helping us to understand any commonalities and differences in turnover valuation between marketing executives and other senior executives. Second, this study posits contextual factors in the form of five research hypotheses that help to explain the market reaction to this appointment. Three of our hypotheses are specific to the marketing function and relate to the signaling value of marketing executive turnover and the appointee's marketing experience. The remaining two hypotheses draw from prior research and relate to appointee origin (insider vs. outsider) and prior firm performance, although arguments that link these hypotheses to the marketing function are also made. Third, this study contributes to a standing debate on the financial relevance of the marketing function (e.g., Rust 2004; Webster, Malter, and Ganesan 2005; Zinkhan and Verbrugge 2000), from an alternative managerial perspective. Last, the results of this paper give rise to a series of managerial implications that are exacerbated by the frequent turnover in the top marketing executive position. The CMO position, according to a recent Spencer Stuart Survey (Welch 2004), is one of the riskiest jobs in America.

\section{THE CHIEF MARKETING OFFICER POSITION}

It is generally accepted that much of the success of the marketing function lies with the quality of the marketing team, as evidenced by the leadership and character of the top marketing executive in the firm. In recent 
years, the role of the top marketing officer has evolved from brand building, advertising effectiveness, and market research to leading company change as a response to evolving buying patterns, managing complexity, and building new marketing capabilities throughout the company as a whole (Court 2007). Thus, the top executive's vision, ability to communicate with and motivate employees, and broader leadership potential, are necessary ingredients for achieving a successful marketing strategy. Starting in the mid-1990's, public firms begun to appoint a Chief Marketing Officer to head the firm's marketing function, in response to the adopting firm's needs in terms of product differentiation, industry affiliation, and marketing strategy. This trend reflects a growing emphasis on market orientation and customer relations. Typically, the CMO is ranked among the executive elite within the firm, being in charge of all facets of marketing activity, and reporting directly to the firm's CEO.

The CMO has a wide range of responsibilities, including strategy development, product development, managing sales and distribution channels, marketing communications such as advertising and promotions, pricing, market research, and customer service. Further, the marketing function is both closely intertwined with, and dependent upon, the other corporate functional areas such as research and development, production, and finance, necessitating that the CMO cooperates with and influences other senior executives to achieve the marketing objectives (e.g., Cadogan, Sundqvist, Salminen and Puumalainen 2005). Given such challenges, the CMO position is often at the epicenter of criticism within firms. Welch (2004) finds that, among the top 100 branded firms, CMO tenure was just 22.9 months, less than half of the corresponding tenure of CEOs. Motivated by the high turnover in the CMO position, and by our incomplete understanding of the nature of this position and its value-relevance, this study pursues an empirical inquiry linking CMO appointments to corresponding changes in shareholder wealth.

\section{THEORY AND RESEARCH HYPOTHESES}

Because of the applied nature of marketing, marketers have been under increasing pressure to show that marketing management matters; most notably, by illuminating the relation between various measures of marketing activity and financial performance. However, there are difficulties in measuring marketing activity reliably and consistently at the firm level, due to insufficient disclosures by firms and the fact most marketing activity measures pertain to organizational subunits and not to the firm as a whole. Second, alternative financial performance measures often fail to capture the "intangible asset" quality of much marketing activity. That is, because of information asymmetry, it is difficult for stock market participants to assess the true quality of marketing activity. In this paper we argue that marketing executive turnover can serve as a signal reducing information asymmetry between management and shareholders about the quality of the firm's marketing activities and products. This, in turn, is reflected on stock prices on the CMO appointment announcement day.

Analogous to prior empirical evidence on CEO turnover, there are mixed predictions about the market reaction to a CMO appointment. One possibility is that a firm voluntarily making such a change seeks to reap the benefits of a redirection in its marketing leadership. To the extent mismanagement of the marketing function contributed to financial problems, a change in leadership is expected to reverse this trend by improving the quality of marketing management in the firm. This, in turn, will help to accelerate the firm's performance recovery. The appointment of a CMO on the top management team is also likely to signal an increase emphasis on market orientation with the potential of improvements on business profitability (Kumar and Peterson 2005; Marvel and Slater 1990; Slater and Marvel 2000). Investors will assimilate expected improvements into their assessment of the announcement, translating into a positive announcement-induced market reaction.

Conversely, a change in CMO is also likely to be associated with certain costs: The market will assimilate the cost of recruiting and training the new CMO. Also, this turnover implies a period of relative inactivity in developing and implementing marketing strategy. Last, a change in CMO is not without risks, given that it is typically associated with a change in the firm's strategic direction. A natural response of the incoming CMO is to question the previous marketing strategy. Increases in advertising expenditures, a visible but often questionable vehicle towards convincing the market of a directional change, may prove fruitless and costly.

In sum, the appointment of CMOs is likely to signal both potential benefits and costs for the appointing firms. In line with such contrasting arguments, a vast body of prior empirical work on CEO turnover has provided mixed results (e.g., Kesner and Dalton 1994; Zajac 1990). In short, the market is unlikely to respond in a consistent 
manner to marketing executive turnover. In a recent study independent of the current paper, Nath and Mahajan (2008) examine factors associated with the presence/absence of CMOs in the top management team and whether the presence/absence of CMOs affects long-term performance. They find no evidence that the presence of CMOs in the top management team has an impact on firm performance. Their tests, however, do not illuminate the sources of performance variation across firms. In the backdrop of both benefits and costs being associated with the CMO position, the main contribution of this paper is to address the variation in performance across firms that adopt the CMO position. Below, we accordingly attempt to obtain more insights on these appointments by positing conditions that help to explain variation in the market's reaction.

\section{Internal Versus External Hire}

The CEO succession literature has studied whether the market's response to the new appointment varies depending on whether the new executive is hired externally as opposed to being promoted from within the firm, with mixed results (e.g., Beatty and Zajac 1987; Karaevli 2007; Lauterbach, Vu, and Weisberg 1999; Lubatkin, Chung, Rogers, and Owers 1989; Zajac and Westphal 1996;). Prior research suggested an internal hire is more likely to possess inside knowledge about the strengths and weaknesses of the company. Also, there is less uncertainty about this person's ability and character increasing the likelihood the appointee will face a friendly supporting cast. The benefits of external hires include the new knowledge they bring in, and the increased likelihood they have been selected at arm's length, away from internal politics. Also, the external labor market provides the company a much larger talent pool from which to choose. An additional benefit of outside appointees that is specific to the marketing function is their increased objectivity in evaluating and challenging the firm's current marketing strategy, and their new and fresh ideas regarding the future direction of the company. Unlike technical positions, where an insider's indepth knowledge of the firm's technology may be beneficial, marketing relies on intangible asset value, rendering a fresh perspective relatively more important than inside knowledge. In sum, given mixed prior findings and countervailing arguments on the value of successor origin, we do not posit a directional expectation. Thus,

$\mathbf{H}_{1}$ : The stock market response to the appointment of a Chief Marketing Officer is not expected to be related to the appointee's origin.

\section{Prior Marketing Executive Experience of the Appointee}

A significant asset of managers is the hands-on experience they have accumulated in the context of their management responsibilities. Managers develop experience by having the opportunity to experiment, try out new ideas and learn from mistakes. Knowledge gained from experience can not be explicitly expressed or taught but is rather tacit real-world intelligence that is developed through time. A number of early studies comparing experts and novices have long suggested that experts have more highly developed cognitive structures. Early research suggested that experts are more likely to search for more and relevant information, which allows for better problem structuring and more successful problem solutions (e.g., Beach 1975; Chi, Feltovich, and Glaser 1981; Chiesi, Spillich, and Voss 1979). In other words, experience affects how managers use information to arrive to decisions and the decisions themselves.

More importantly, experience is likely to be more useful in more uncertain and unstructured situations where managers have to make decisions relying on broader and "softer" information (e.g., Perkins and Rao 1990). ${ }^{1}$ As such, experience is likely to be especially important for the CMO of the firm who has to operate and make decisions in an uncertain and volatile environment. Consistent with this notion, the experience and past accomplishments of the new appointee are typically emphasized in the CMO appointment announcement. Importantly, whereas all CMO appointees are expected to have some relevant work experience, the distinguishing characteristic of a seasoned appointee will be experience as a senior executive at the marketing helm of a firm (e.g., as a CMO, vice president of Marketing, or Vice President of Sales). Prior marketing executive experience is expected to be, on average, superior to experience in lower level positions. Given the above arguments we expect the market to value senior marketing executive experience.

$\mathbf{H}_{2}$ : The stock market response to the appointment of a Chief Marketing Officer is expected to be greater when the new executive has prior experience as a marketing executive. 


\section{Marketing Strategy Disclosure}

We further distinguish companies into those where the new CMO comments on the intended future marketing strategy on the appointment day, and those where the CMO does not provide any such information. In a distinct group of appointment announcements, the newly appointed CMO opts to discuss the company's current position in the marketplace, and future marketing plans, albeit with a considerable degree of variation in extent and level of detail.

Although such comments may not be specific enough to allow disentangling specific strategic directions across announcements, there is a clear distinction between the new executives that at least announce a broad plan from those that do not. ${ }^{2}$ This distinction may be due to many factors. For example, a comment from the new executive may signify the CMO's relative power and visibility and/or the perceived importance of the marketing function in the appointing firm. Thus, we expect and argue that shareholders assess more favorably newly appointed marketing executives who are more visible and more powerful. Similarly, a change in marketing leadership is likely to be more value relevant in firms where the marketing function is relatively more important in the organization.

Another explanation is that new executives that announce future plans signal their confidence in their ability to deliver on pre- appointment promises. Therefore we expect managers that have better information about future plans or ones that have "good news" (that is, ones expecting to deliver on their promises), to be more likely to make an announcement. In a related vein, Gunz and Jalland (1996) and Tushman and Rosenkopf (1996), among others, highlight how a change in strategy may serve as a positive signal about the firm's prospects. Conversely, in cases where the executive does not make any comment about future plans the market is likely to perceive this as a negative signal because of adverse selection (i.e., in the absence of good news to disclose, lack of adequate information, or a clear vision on how to get the firm out of a difficult situation, a new appointee may self-select into being silent on the matter, a signal perceived negatively by the market). ${ }^{3}$ Thus,

$\mathbf{H}_{3}$ : The stock market response to the appointment of a Chief Marketing Officer is expected to be greater when the new executive discloses some information about future marketing strategy.

\section{Prior Share Price Performance}

In general, a deteriorating stock price may be an especially relevant determinant of an executive change. When the firm's shareholders are not content with the firm's performance there is high pressure on the board of directors and the CEO to make drastic changes, that would turn the situation around. This pressure some time results in top executive turnover, and in other times to the hiring of an executive that could potentially improve firm performance. Many prior studies found that likelihood and mode of executive turnover, as well as the market reaction to executive appointments depend on the firm's prior share price and operating performance (e.g., Canella and Lubatkin 1993; Friedman and Singh 1989; Ocasio 1994; Zhang and Rajagopalan 2004).

Marketing, among the firm's major corporate functions, is most likely to be blamed when performance is poor and the reasons for failure are unclear. The Spencer Stewart survey finding of average CMO tenure lengths measuring less than two years, much less than the tenure of other major corporate executives, is clearly consistent with this conjecture. Therefore, appointing a new executive to lead the marketing function signals a change in direction and strategy with the potential for quick turnaround and improved performance. That is, a CMO appointment is likely to be viewed as a partial remedy to a firm's previous stock market problems. On the other hand, an appointment made under duress may be deemed reactive by investors. In the present setting, a CMO appointment following poor prior share price performance is tentatively expected to be assessed more favorably by the stock market. Therefore,

$\mathbf{H}_{4}$ : The stock market response to the appointment of a Chief Marketing Officer is expected to be negatively related to a firm's prior share price performance. 


\section{High Technology Industry}

Historically, high-tech companies relied on their unique technological advantage, and an aggressive highly motivated sales force to remain competitive. The belief that a superior product will sell itself, and that a firm is only as good as its latest product, resulted in less reliance on marketing strategies, where the marketing function was largely ignored and diminished to sales management and support services (e.g., Workman 1993). In contrast, in more saturated, lower growth industries, products are likely to have fewer distinguishing selling points making marketing more important. Given the special characteristics of high-technology industries, there is an ongoing debate in the marketing literature on whether conventional marketing tools are well suited in these industries (e.g., John, Weis, Dutta 1999).

The different roles of, and the different emphasis placed on the marketing function in high-tech as compared to low-tech industries is also likely to affect the role the top marketing executive is expected to play in the firm and the top executive's potential to contribute to firm value. Specifically, responding to crisis by replacing a marketing executive in a high-tech firm may send a negative signal to the market about the firm's fundamental quality; i.e., that the firm has trouble competing on the basis of its product, as is expected in high-tech industries, and has to resort to changes in marketing strategy for future growth. Such a change would be less scrutinized in a low-tech firm where products are less differentiated, and marketing is relatively more important. Therefore, ceteris paribus, we expect a lower market reaction to an appointment of a CMO in a high-technology firm.

H: $\quad$ The stock market response to the appointment of a Chief Marketing Officer is lower for firms belonging to a high technology industry.

\section{METHODS}

\section{Sample Selection}

The sample comprises announcements of appointments to the Chief Marketing Officer position that appeared in the Lexis-Nexis database during the period from 1999 to 2005. Lexis-Nexis includes, in electronic form, articles published by a vast number of newspapers in the United States and is considered to be a reliable source of first-time public releases of information typically used in event-studies. The time period was constrained by the fact the CMO title is a relatively new development, with few executives holding this title in the 1990's, and consequently only rare announced appointments to the CMO position before our sample period. ${ }^{4}$ CMO appointment announcements were excluded when they i) contained other major potentially confounding news; ii) pertained to subsidiary executives; and iii) were made by private firms. A total of 166 observations pass these screening criteria and comprise our CMO sample.

Table 1

Time distribution of 166 announcements of new Chief Marketing Officer appointments occurring between 1999 and 2005.

\begin{tabular}{ccc}
\hline Year & Number of Events & Pct. Sample \\
\hline 1999 & 18 & $10.8 \%$ \\
2000 & 24 & $14.5 \%$ \\
2001 & 24 & $14.5 \%$ \\
2002 & 15 & $9.0 \%$ \\
2003 & 25 & $15.1 \%$ \\
2004 & 29 & $17.5 \%$ \\
2005 & 31 & $18.7 \%$ \\
\hline Total & $\mathbf{1 6 6}$ & $\mathbf{1 0 0 . 0 \%}$ \\
\hline
\end{tabular}

Table 1 presents the distribution of the 166 firm-announcements through time. In general, the announcements are fairly evenly distributed temporally with a slight increase in the number of events in years 2004 and 2005. The highest number of announcements occurs in $2005(\mathrm{n}=31 ; 18.7 \%$ of the sample) and the lowest in $2002(n=15 ; 9.0 \%$ of the sample). 


\section{Variable Measures}

To measure the firm's stock price performance around the appointment announcement this paper uses standard event study methodology. Specifically, abnormal (excess) stock return for any one security on a given day is defined as the firm's raw return for that day minus the normal return of the firm over the event window given by a one-factor market model (using the equally weighted CRSP index to proxy for the market rate of return). To estimate the market model, a 256-day estimation period is used that begins 300 days before the event day, on $\mathrm{t}=-300$, and ends 45 days before the event day, on $\mathrm{t}=-45$.

The text of the announcement is used to create three explanatory variables: to distinguish between internal and external appointees; to separate appointees with prior experience in the top marketing position from all others; ${ }^{5}$ and to distinguish between executives that provide an indication of their future marketing strategy from those that do not. To assess the pre-appointment stock price performance of the sample firms we considered market-adjusted returns spanning approximately one year (250 trading days) ending five days prior to the event day.

To evaluate the industry effect on the announcement we classify firms into those affiliated with a hightechnology vs. a low-technology industry. Following Bushee, Matsumoto, and Miller (2003), a firm is classified as operating in a low technology industry if it operates in a four-digit Standard Industrial Classification code other than 2833-2836, 3612-3613, 3621-3629, 3651-3652, 3661-3669, 3671-3672, 3674, 3695, 4812-4822, 4832-4899, and 7370-7379. ${ }^{6}$ Finally we control for firm size using the natural logarithm of total assets. ${ }^{7}$

\section{The empirical model}

Initially, we assess whether the stock price performance of the sample firms before and during the appointment is significantly different from zero. To this end we employ a t-test and a signed-ranks test, two-tailed. More importantly, to examine our five hypotheses, we link the appointment-related abnormal return to the variables of interest as follows:

$$
\begin{aligned}
\operatorname{CAR}_{\mathrm{i}}\left(\tau_{1} \tau_{2}\right)=\beta_{0}+\beta_{1} \text { internal }_{\mathrm{i}}+\beta_{2} \text { experience }_{\mathrm{i}}+\beta_{3} \text { strategy }_{\mathrm{i}}+\beta_{4} \text { prior return }_{\mathrm{i}}+\beta_{5} \text { high tech }_{\mathrm{i}}+ \\
\beta_{6} \log \left(\text { assets }_{\mathrm{i}}+\varepsilon_{\mathrm{i}}\right.
\end{aligned}
$$

where,

$\operatorname{CAR}_{\mathrm{i}}\left(\tau_{1} \tau_{2}\right)=$ cumulative abnormal returns of security $\mathrm{i}$ during the event window

internal $=\quad$ one if the $\mathrm{CMO}$ is appointed from inside the firm, zero otherwise

experience $=\quad$ one if the CMO served as a top marketing executive at any time prior to the appointment, zero otherwise.

strategy $=\quad$ one if the new CMO comments on future marketing plans and strategy, zero otherwise.

prior return $=\quad$ cumulative market-adjusted excess return from trading day -255 to trading day -5 relative to the appointment announcement.

high tech $=\quad$ one if the firm operates in a high technology industry, defined earlier, and zero otherwise.

$\log ($ assets $)=\quad$ the natural logarithm of total assets (Compustat data item \#6) at the end of the fiscal year prior to the announcement.

\section{ANALYSES AND RESULTS}

\section{Univariate tests and correlations}

The tests initially examine share price behavior before and during CMO appointments. Results are presented in table 2. Two patterns are noteworthy: First, as expected, the appointment of a new CMO executive is preceded by deteriorating share price performance for the adopting firms. The median market-adjusted return is $18.57 \%(-10.65 \%)$ in the $250(150)$ trading days leading to the new appointment announcement. Both windows are statistically significant at $p<0.01$ under the non-parametric test and at $p<0.10$ and $p<0.01$, respectively, under the parametric test. 
Table 2

Excess returns around an announced appointment of a new Chief Marketing Officer

\begin{tabular}{|c|c|c|c|c|}
\hline \multicolumn{2}{|c|}{ Cumulative excess returns } & \multirow{2}{*}{$\begin{array}{c}\text { Sample size } \\
166\end{array}$} & \multirow{2}{*}{$\begin{array}{c}\text { Mean } \\
-8.63 \% *\end{array}$} & \multirow{2}{*}{$\begin{array}{c}\text { Median } \\
-18.57 \% * * *\end{array}$} \\
\hline Pre-event: & $(-255,-5)$ & & & \\
\hline \multirow{3}{*}{ Event- period: } & $(-155,-5)$ & 166 & $-10.69 \% * * *$ & $-10.65 \% * * *$ \\
\hline & $(-2,2)$ & 166 & $-0.80 \%$ & $-0.58 \% * *$ \\
\hline & $(-1,1)$ & 166 & $-0.04 \%$ & $-0.55 \%$ \\
\hline
\end{tabular}

Note. The pre-event cumulative excess returns are computed by subtracting equally weighted market returns. The event-period excess returns are the residual returns from a 255-trading day market model. The significance asterisks in the median column are based on the non-parametric Wilcoxon signed ranks test. $* * *, * *, *$ indicate levels of significance for $1 \%, 5 \%$, and $10 \%$, respectively. All variables are winsorised at $2 \%$ and $98 \%$ to tone down the effect of outliers.

Focusing on the announcement-induced return the results suggest a somewhat weak, negative market response to the CMO appointment announcement date. More specifically, there is $-0.55 \%$ median abnormal return in the $(-1,1)$ event window that is not statistically significant, and a $-0.58 \%$ median cumulative abnormal return in the $(-2,2)$ event window that is statistically significant at $p<0.05$ under the non-parametric signed test. It therefore appears that the market does not interpret, at least on average, that the CMO appointment is a meaningful step towards improving firm value. As discussed in our hypothesis development section, the market's uncertainty in evaluating this announcement renders our attempts to explain fluctuations in the market reaction all the more interesting.

Table 3

Mean and median values (panel A) and Pearson correlations (panel B) for the variables used in the sample regressions Panel A - Descriptive statistics

\begin{tabular}{lcc}
\hline Variable Name & Mean & Median \\
\hline Fraction of firms appointing a CMO from within the firm & $17.47 \%$ & 0.0 \\
Fraction of new CMOs with prior top marketing experience & $63.86 \%$ & 1.0 \\
Fraction of firms where the CMO makes a strategy announcement & $51.20 \%$ & 1.0 \\
Fraction of firms in a high tech industry & $50.00 \%$ & 0.5 \\
Assets (in millions of dollars) & 6209.4 & 561.526 \\
\hline
\end{tabular}

Panel B - Pearson correlations between the variables of interest

\begin{tabular}{|c|c|c|c|c|c|c|c|c|}
\hline & Variable name & 1 & 2 & 3 & 4 & 5 & 6 & 7 \\
\hline 1 & Cumulative excess return $(-2,+2)$ & 1 & & & & & & \\
\hline 2 & Internal appointee & -0.08 & 1 & & & & & \\
\hline 3 & Experience as a marketing executive & 0.03 & $-0.15^{*}$ & 1 & & & & \\
\hline 4 & Marketing strategy disclosure & $0.19 * *$ & -0.12 & -0.01 & 1 & & & \\
\hline 5 & Prior stock returns $(-255,-5)$ & $-0.15^{*}$ & 0.05 & 0.02 & -0.05 & 1 & & \\
\hline 6 & High technology industry & -0.10 & $-0.17 * *$ & 0.05 & $0.25 * * *$ & 0.12 & 1 & \\
\hline 7 & Log (assets) & 0.02 & 0.13 & -0.02 & $-0.32 * * *$ & -0.05 & $-0.31 * * *$ & 1 \\
\hline
\end{tabular}

Note. $* * *, * *, *$ indicate levels of significance for $1 \%, 5 \%$, and $10 \%$, respectively. All variables are winsorised at $2 \%$ and $98 \%$ to tone down the effect of outliers

Next, table 3 presents variable descriptive statistics (panel A) and Pearson correlations between them (Panel B). Notably, only $17.47 \%$ of CMO appointments are promotions from inside the firm, signifying a preference for outside executives. More than half of the appointees (63.86\%) have experience in top marketing executive positions prior to the present appointment. Approximately half of the new CMOs (51.20\%) briefly sketch their marketing strategy and future plans in the appointment announcement. Also, exactly half of the firms that announce hiring a new CMO officer operate in a high technology industry. Last, the average firm in the sample had 6.209 billion dollars in total assets in the pre-appointment fiscal year. The pairwise correlations in panel B suggest the market reaction is positively correlated with the new CMO's comments on strategy, and negatively correlated with 
prior share price performance. Although these pair-wise effects are in line with hypotheses 3 and 4 , more definitive evidence is provided through the multivariate regressions, discussed below.

\section{Multiple regression analysis}

We performed the multivariate analysis using robust regressions (e.g., Huber, 1981). Robust regression is a form of weighted least squares that provides stable results by limiting the influence of outliers. ${ }^{8}$

Table 4

Robust regressions of factors explaining the cross-sectional variation to the market reaction to Chief Marketing Officer appointments

\begin{tabular}{|c|c|c|c|c|}
\hline Parameter & Predicted Sign & MODEL 1 & MODEL 2 & MODEL 3 \\
\hline Intercept & & $\begin{array}{c}-0.066^{* * *} * \\
(0.002)\end{array}$ & $\begin{array}{l}-0.006 \\
(0.767)\end{array}$ & $\begin{array}{c}-0.072 * * * \\
(0.001)\end{array}$ \\
\hline Internal appointee & $?$ & $\begin{array}{c}-0.006 \\
(0.688)\end{array}$ & & $\begin{array}{l}-0.007 \\
(0.602)\end{array}$ \\
\hline Experience as a marketing executive & + & $\begin{array}{c}0.024 * * \\
(0.026)\end{array}$ & & $\begin{array}{c}0.024 * * \\
(0.025)\end{array}$ \\
\hline Marketing strategy disclosure & + & $\begin{array}{l}0.020 * \\
(0.059)\end{array}$ & & $\begin{array}{c}0.022 * * \\
(0.046)\end{array}$ \\
\hline Prior stock returns $(-255,-5)$ & - & & $\begin{array}{c}-0.021 * * * \\
(0.005)\end{array}$ & $\begin{array}{c}-0.019 * * * \\
(0.009)\end{array}$ \\
\hline High technology industry & - & & $\begin{array}{c}-0.028 * * \\
(0.010)\end{array}$ & $\begin{array}{c}-0.034 * * * \\
(0.002)\end{array}$ \\
\hline Log (assets) & $?$ & $\begin{array}{c}0.004 \\
(0.121)\end{array}$ & $\begin{array}{c}0.000 \\
(0.966)\end{array}$ & $\begin{array}{c}0.002 \\
(0.543)\end{array}$ \\
\hline $\begin{array}{l}\text { R-Squared } \\
\text { AICR } \\
\text { BICR }\end{array}$ & & $\begin{array}{c}4.10 \% \\
172.401 \\
191.910\end{array}$ & $\begin{array}{c}4.66 \% \\
132.853 \\
149.245\end{array}$ & $\begin{array}{c}8.72 \% \\
135.289 \\
164.228\end{array}$ \\
\hline
\end{tabular}

Note. The dependent variable is the five-day cumulative excess return measured from two days before to two days after the announcement using the market model. AICR is a counterpart of the Akaike criterion for robust regression, and BICR is a robust version of the Schwarz information criterion. $* * *, * * *$ indicate levels of significance for $1 \%, 5 \%$, and $10 \%$, respectively. pvalues are in parentheses.

Table 4 presents the results from robust regressions linking the market reaction to the appointment to the variables of interest. Three models are estimated. Model 1 presents results for the three variables that are drawn from the appointment itself, model 2 presents results from the two firm-specific variables, and the last model presents results on the full array of hypothesized effects. The results reveal no difference in the abnormal returns of firms appointing an external hire compared to those appointing an internal CMO, in line with mixed prior evidence. Models 1 and 3, however, provide strong evidence that the market values CMO experience. In both models, the variable capturing senior marketing experience is positive and statistically significant at $p<0.05$. Consistent with hypothesis two of the paper, experience is an asset that the market deems significant in a new CMO, expecting it will help the new executive enhance firm value.

Consistent with the study's third hypothesis, models 1 and 3 show that there is a significantly positive relation between strategy announcements and abnormal stock returns ( $<<0.10$ and $\mathrm{p}<0.05$, respectively). This finding is consistent with a signaling story, where the market perceives comments by new executives as an indication that they are more informed, and/or more confident about their ability to deliver results. Also, models 2 and 3 provide evidence that is consistent with hypothesis four of the paper, suggesting that when prior performance is poor the market welcomes a change in the executive team: prior excess returns are negatively related to event period abnormal returns $(\mathrm{p}<0.01)$.

Last, models 2 and 3 show that firms in high technology industries elicit significantly lower abnormal 
returns ( $p<0.05$ and $p<0.01$ respectively) compared to firms in low tech industries. This finding suggests that the market perceives the CMO leadership change to be less useful for high-tech firms. This could be because the market values high tech firms on the strength of their innovative and technologically advanced products. (E.g., in the computer chip industry, sales may be driven by product-based, specification-based concerns rather than promotion and distribution.) Ceteris paribus, the market perceives the change in marketing leadership as a sign of weakness (negative signal) about the fundamental quality of the firm's products. In a low tech firm, where products are typically less differentiated, firms are expected to rely more on marketing strategy for their success.

\section{CONCLUSIONS}

Our study's results have the following managerial implications: First, boards and CEOs should pay particular attention to senior executive experience in hiring marketing executives. Marketing is a hands-on discipline, where practical experience appears to be a relatively important characteristic. Second, investors place greater value in marketing executives who "hit the ground running"; those having a clear vision about their future marketing strategy and who are willing to share some of this information with market participants. Finally, top managers in high technology firms should bear in mind that the market primarily relies on the strength of their firm's products. Top management teams in high-tech firms that respond to crises through a focus on the marketing function, such as by replacing marketing executives, send a negative signal to the market about the strength of their company's products.

In closing, and taking the results at face value, this study adds to a growing body of evidence linking executive turnover to corporate financial performance, highlighting the importance of appointee experience and strategic vision. Also, this paper suggests that the quality of marketing management in a public corporation, a relatively unexplored venue, is empirically related to share price performance. Most importantly, the assessment of a change in marketing leadership should not be viewed as uniformly positive or negative, but should be assessed against the characteristics of the appointee, the profile of the appointing firm, and the characteristics of the industry in which the firm operates.

\section{AUTHOR INFORMATION}

Nikos Vafeas is a Professor of Accounting at the University of Cyprus. His research primarily encompasses topics from accounting, and secondarily from strategy and finance. He has published around forty articles in refereed academic journals, including the Journal of Financial Economics, Journal of Accounting Research, Academy of Management Journal, Strategic Management Journal, and Contemporary Accounting Research. He also serves on four journal editorial boards.

Adamos Vlittis is an Assistant Professor at the University of Nicosia. He completed his Ph.D in Accounting at the University of Florida in 2005, his M.Sc. in Finance at the Imperial College in London and his B.Sc. in Business Administration at the University of Cyprus.

\section{REFERENCES}

1. Akerlof GA. 1970. "The market for 'lemons': Quality uncertainty and the market Mechanism.” Quarterly Journal of Economics 84(3): 488-500.

2. Beach BH. 1975. "Expert Judgment About Uncertainty: Bayesian Decision Making in Realistic Settings." Organizational Behavior and Human Performance, 14(1): 10-59.

3. Beatty RP, Zajac EJ. 1987. "CEO change and firm performance in large corporations: Succession effects and manager effects." Strategic Management Journal 8(4): 305-317.

4. Bruton GD. Wan CC. 1994. "Operating Turnarounds and High Technology Firms." The Journal of High Technology Management Research 5(2): 261-278.

5. Bushee BJ, Matsumoto DA, Miller GS. 2003. "Open versus Closed Conference Calls: The Determinants and Effects of Broadening Access to Disclosure.” Journal of Accounting \& Economics 34(1-3): 129-147.

6. Cadogan W.J., Sundqvist S., Salminen T. R., Puumalainen K. 2005. "Export marketing, interfunctional 
interactions, and performance consequences." Journal of the Academy of Marketing Science 33(4): 520535 .

7. Canella AA, Lubatkin M. 1993. "Succession as a sociopolitical process: internal impediments to outsider selection." Academy of Management Journal 36(4): 763-794.

8. Chi M, Feltovich PJ, Glaser R. 1981. "Categorization and Representation of Physics Problems by Experts and Novices." Cognitive Science 5(2): 121-52

9. Chiesi HL, Spillich GJ, Voss JF. 1979. "Acquisition of Domain-Related Information in Relation to High and Low Domain Knowledge." Journal of Verbal Learning and Verbal Behavior 18(3): 257-73.

10. Court, D. 2007. "The evolving role of the CMO" Mckinsey Quarterly 3: 28-39.

11. Davidson W, Worrell D, Cheng L. 1990. "Key executive succession and stockholder wealth: the influence of successor's origin, position, and age." Journal of Management 16(3): 647-664.

12. Davies W. Brush KE. 1997. "High-Tech Industry Marketing: The Elements of a Sophisticated Global Strategy." Industrial Marketing Management 26(1): 1-13.

13. Finkelstein S. 1988. "Managerial orientations and organizational outcomes: the moderating roles of managerial discretion and power." Ph.D. dissertation, Columbia University.

14. Friedman SD, Singh H. 1989. "CEO succession and stockholder reaction: The influence of organizational context and event content." Academy of Management Journal 32(4): 718-744.

15. Gunz HP, Jalland RM. 1996. "Managerial careers and business strategies." Academy of Management Review 21(3): 718-756.

16. Hambrick DC, Canella AA. 2004. "CEOs who have COOs: contingency analysis of an unexplored structural form." Strategic Management Journal 25(1): 959-979.

17. Hambrick DC, Cho TS, Chen M. 1996. "The influence of top management team heterogeneity on firms' competitive moves." Administrative Science Quarterly 41(4): 659-684.

18. Huber PJ. 1981. Robust Statistics. John Wiley \&Sons, New York.

19. John GA, Weiss M. Dutta S. 1999. "Marketing in high-technology markets: Towards an integrative framework." Journal of Marketing 63 (special issue): 78-91.

20. Karaevli, A. 2007. "Perfomance consequences of new CEO "outsiderness": Moderating effects of pre- and post-succession contexts." Strategic Management Journal 28(7): 681-706.

21. Kesner I.F, Dalton D.R. 1994. "Top management team turnover and CEO succession: An investigation of the effects of turnover on performance.” Journal of Management Studies 31(5): 701-713.

22. Kumar V., Peterson J. A. 2005. "Using a customer-level marketing strategy to enhance firm performance: a review of theoretical and empirical evidence." Journal of the Academy of Marketing Science 33 (4): 504519.

23. Lauterbach B, Vu J, Weisberg J. 1999. "Internal vs. external successions and their effect on firm performance.” Human Relations 52(12): 1485-1504.

24. Lee, PM, and James EH. 2007. "She-E-Os: Gender effects and investor reactions to the announcements of top executive appointments." Strategic Management Journal 28(3): 227-241.

25. Lubatkin MH, Chung KH, Rogers RC, Owers JE. 1989. "Stockholder reaction to CEO changes in large organizations." Academy of Management Journal 32(1): 47-68.

26. Narvel C.J., Slater, F.S. 1990. "The effect of market orientation on business profitability" Journal of Marketing 54: 20-35.

27. Nath, P., and Mahajan V., 2008. “Chief Marketing Officers: A Study of Their Presence on in Firms' Top Marketing Team.” Journal of Marketing 72: 65-81.

28. Neelankavil JP, Alganar VT. 2003. "Strategic Resource Commitment of High-Technology Firms: An International Comparison." Journal of Business Research 56(6): 493-502.

29. Ocasio W. 1994. "Political dynamics and the circulation of power: CEO succession in U.S. industrial corporations, 1960-1990.” Administrative Science Quarterly 39(2): 285-312.

30. Perkins WS, and Rao RC. 1990. "The Role of Experience in Information Use and Decision Making by Marketing Managers.” Journal of Marketing Research 27(1),1-10

31. Pfeffer J, Davis-Blake A. 1986. “Administrative succession and organizational performance: how administrator experience mediates the succession effect." Academy of Management Journal 29(1): 72-83.

32. Rust R. 2004. "The Maturation of Marketing as an Academic Discipline." Journal of Marketing 70 (3), 12.

33. Slater, F.S., Narvel C.J. 2000. "The positive effect of market orientation on business profitability: a 
balanced replication." Journal of Business Research 48: 69-73.

34. Smith BF, Amoako-Adu B. 1999. "Management succession and financial performance of family controlled firms." Journal of Corporate Finance 5(4): 341-368.

35. Sorescu A, Shankar V, Kushwaha T. 2007. "New Product Preannouncements and Shareholder Value: Don't Make Promises you Can't Keep.” Journal of Marketing Research 44 (3), 468-489.

36. Tushman ML, Rosenkopf L. 1996. "Executive succession, strategic reorientation, and performance growth: a longitudinal study in the U.S. cement industry." Management Science 42(7): 939-953.

37. Webster F, Malter A, Ganesan S. 2005. "The Decline and Dispersion of Marketing Competence." Sloan Management Review 46 (4), 35-43.

38. Welch G. 2004. "CMO tenure: Slowing Down the Revolving Door.” SpencerStuart, Blue Paper.

39. Workman JP. 1993. "Marketing's limited role in new product development in one computer systems firm." Journal of Marketing Research 30(4): 405-21.

40. Zajac EJ. 1990. "CEO selection, succession, compensation, and firm performance: a theoretical integration and empirical analysis." Strategic Management Journal 11(3): 217-230.

41. Zajac EJ, Westphal JD. 1996. "Who shall succeed? How CEO/board preferences and power affect the choice of new CEOs." Academy of Management Journal 39(1): 64-90.

42. Zhang Y. 2006. "The presence of a separate COO/president and its impact on strategic change and CEO dismissal." Strategic Management Journal 27(3): 283-300.

43. Zhang Y, Rajagopalan N. 2004. "When the known devil is better than an unknown god: an empirical study of the antecedents and consequences of relay CEO successions." Academy of Management Journal 47(4): 483-500.

44. Zinkhan M. G., Verbrugge J. A. 2000. "The marketing/finance interface: two divergent and complementary views of the firm" Journal of Business Research 50(2): 143-148.

\footnotetext{
${ }^{1}$ Smith and Amaoko-Adu (1999) report a negative stock market response to the appointment of younger, and thus less experienced successors in family controlled firms. Other CEO turnover studies, such as Davidson, Worrell, and Cheng (1990), and Karaevli (2007) similarly control for appointee age, although not explicitly claiming this to be a control for appointee experience. In a study on NFL coaches, Pfeffer and Davis-Blake (1986) report a positive effect of experience in mitigating the effect of succession on organizational performance.

${ }^{2}$ We also attempted to go deeper into the CMO strategic direction by codifying the CMO's discussion on future plans. However, the broadness of the announcement makes it difficult to objectively distinguish between different strategies. So, at the cost of sacrificing useful information, we opted to stay with the simple binary distinction in order to avoid the subjectivity bias.

${ }^{3}$ Similar arguments are made in the economics literature on voluntary disclosures. This discussion has its roots in the "lemons problem" described by Akerlof (1970). It should be emphasized that the CMO strategy disclosure is a credible signal because it is costly to replicate. In a repeated game, if a marketing executive attempts to send a false positive signal by making strategy statements that do not correspond to the truth, any future communications of the executive with the market will be discounted accordingly. Sorescu, Shankar, Kushwaha (2007) provide evidence consistent with this theory in strategic new product preannouncements.

${ }^{4}$ It should be emphasized that we expect a negligible effect of corresponding marketing executive departures on our results for the following reasons: First, several appointments reflect the creation of a new CMO position, or the upgrading of an existing marketing executive position (i.e., there is no departing executive). Also, even when there is a departing executive, the hiring and severance announcements appear to be separated in time, thus producing distinct effects on stock prices. To further address this point we examined the proxy statements of each of the candidate firms for up to two years prior to the CMO appointment announcement and controlled for all firms that had a top marketing executive in place at any time during the previous two years. Removing or controlling for these cases has no bearing on our results.

${ }^{5}$ Although it is less likely for an internal appointee to have held a lead marketing position at another firm, the correlation of the internal affiliation and experience variables is only -0.15 , suggesting they capture substantially different concepts.

6 There is no one universally accepted empirical measure to capture high technology firms. Suggested criteria include the proportion of $R \& D$ employment, the intensity of technology-oriented workers, and the use of high tech production methods and processes (e.g., see Bruton and Wan 1994). In our paper we used two alternative proxies to measure high technology: 1)R\&D spending, deflated by sales, drawing data from Compustat, and 2) the SIC industry classification suggested by Neelankavil and Alganar (2003). In both cases, the statistical results on this variable were similar to results reported in this paper.

${ }^{7}$ In further tests (results not tabulated), we additionally controlled for appointee gender (Lee and James, 2007), education (e.g., Finkelstein, 1988) and, where available, appointee age (e.g., Karaevli, 2007). Results on these variables where insignificant. To retain higher model parsimony, these results are not reported in the paper.

${ }^{8}$ Similar results are obtained using linear regression with or without winsorizing the dependent variable.
} 


\section{NOTES}

